\title{
Metabolic and Molecular Profiling of Microbial Communities Following Controlled Kerosene Pollution
}

\author{
Ioana Mereuta, Ana-Maria Tanase*, Iulia Chiciudean, Tatiana Vassu, Ileana Stoica \\ Department of Genetics, Faculty of Biology, University of Bucharest, Bucharest, Romania
}

Received: 3 July 2018

Accepted: 3 September 2018

\begin{abstract}
The release of xenobiotic compounds as petroleum and its derivatives still represents a problematic and not fully manageable consequence of various anthropogenic activities. Thus, endogenous microbial communities facing such pollutants are constantly adapting to new conditions, their evaluation being an important asset for environmental preservation. This study analyzes structural and metabolic shifts in a soil microbial community following kerosene pollution. Metabolic profiles from Biolog EcoPlate, analyzed as a guild grouping, Shannon diversity index ( $\mathrm{H}$ index) and functional divergence revealed a significant reorganization followed by specialization in communities' metabolic function, also being supported by molecular profiles from ribosomal RNA ( $r R N A)$ intergenic spacer analysis (RISA) fingerprinting. Highly intense metabolic activity and structural changes are suggested by the increase in alkB and $r R N A$ genes copy number, having similar trends. Thus, alkB gene copy number increased in 70 days from $5.53 \times 10^{9}$ to $1.67 \times 10^{11}$ copies. In this study we managed to report the changes that occur in a soil microbial community facing kerosene pollution using a significant number of complementary techniques, resulting in a complex characterization that can be of great use when facing kerosene-type pollutants.
\end{abstract}

Keywords: kerosene pollution, metabolic profiling, risa, alkB copy number, $16 S \mathrm{r} R N A$ copy number

\section{Introduction}

Modern society's demand for petroleum and its derivatives is constantly increasing, leading to anthropogenic pollution with a great variety of xenobiotic compounds, mostly due to processing, transportation and improper stocking. Thus, all types of ecosystems can be compromised, endangering human well-being

*e-mail: ana-maria.tanase@bio.unibuc.ro as well as wildlife and plants, the last one having a main role in the living world [1]. Plants perform many ecological functions in their environment, shaping the life of all living things that become directly or indirectly dependent on plants [2,3]. The ability of plants to fulfil their functions primarily depend on the appropriate climatic and edaphic conditions [4]. Therefore, the complex structure of soil alongside the biological and biochemical processes mediated by microorganisms represent the basis of a terrestrial ecosystem, as well as its relationship with plants [5-7]. 
During the last decades, increasing pollution has become a major concern for worldwide authorities engaging scientists in finding eco-friendly alternatives and, most important, developing efficient methods for remediation of damaged ecosystems [8,9]. The latest research has described bioremediation as being the most promising method in comparison with conventional, physicochemical methods, being both technically and economically viable [10]. Bioremediation relies on the ubiquity and versatility of microorganisms being able to adapt to new unfavorable conditions, having the capacity to utilize a great variety of pollutants as the sole source of carbon converting them to less or nontoxic compounds [11-13]. For an increased remediation efficiency besides microorganism, plants are also used in decontamination of soil, mostly in heavy metals pollution [14-16] Even if a significant number of bioremediation technologies has been elaborated upon and implemented, considering the great abilities of microorganisms, natural attenuation can still represent the first and easiest choice in environmental cleaning. Thus, numerous studies are focused on microbial communities' structural dynamics from polluted sites, as a measurement of ecosystem state [8, 17-19]. In assessing microbial community structure, the most suitable approach are ones based on metagenomics $[20,21]$. Even though high-quality DNA retrieval from environmental samples is problematic [22], and the great amount of data can be difficult to analyze, the evaluation of culturable and unculturable microorganisms offers a more complex and comprehensive view on microbial community structure [23] to laboratory cultivation approach. Even if molecular assays are best suited for community structure evaluation, to get a bigger picture, one must also address the metabolic activity. Biolog EcoPlates are used as a proper method in assessing the metabolic profile, represented by the capacity to grow on 31 different carbon sources, of a community at a given time point [24-27]. However, data processing and interpretation can be problematic, and various studies are still focusing on finding the most appropriate way to cover all data [28-30].

This study follows the dynamics of an indigenous microbial community during kerosene pollution, using an outdoor microcosm system. Structural changes were represented by molecular community fingerprinting by ribosomal intergenic spacer analysis (RISA) and assessment of the total number of bacteria from soil via quantitative PCR. Metabolic arrays were realized using EcoPlates, and hydrocarbon degradation potential and rate were determined by alkB gene quantification.

\section{Material and Methods}

\section{Study Site and Sampling}

Experimental soil, $120 \mathrm{~kg}$, retrieved from a botanical garden (Bucharest, Romania) was air-dried, ground, sieved and loaded into a $512 \mathrm{~L}$ glass tank. To simulate naturally occurring processes, the tank was buried outdoors at a depth of $0.4 \mathrm{~m}$. Soil characteristics were as follows: $\mathrm{pH}$ 6.94; humic acids $60.86 \%$; conductivity $154.3 \mu \mathrm{S} / \mathrm{cm}$. Subsequently, the microcosm system was intentionally polluted with $58.8 \mathrm{~g} / \mathrm{kg}$ kerosene and regularly aerated and humidified. Samples were collected before and after pollution at 7, 14, 30, 50, 70, 80 days. Each sample consisted of soil collected from 5 points of the microcosm.

\section{Community-Level Physiological Profiling}

Metabolic profiles of microbial community at given time points were obtained using EcoPlates (BIOLOG Inc., Hayward CA., USA) consisting of 96 wells, with 31 different carbon sources and a water blank, in triplicate. The EcoPlates inoculum was represented by $20 \mathrm{~g}$ of sampled soil mixed with deionized sterile water (v:v) incubated for 2 hours at $25^{\circ} \mathrm{C}$ and $150 \mathrm{rpm}$, followed by $10 \mathrm{~min}$ vortexing. From obtained suspension, 10-fold serial dilutions of up to 10-6 were performed. EcoPlates were inoculated from each dilution with $150 \mu \mathrm{l} /$ well and incubated at $28^{\circ} \mathrm{C}$. Absorbance readings were taken at $590 \mathrm{~nm}$ using a plate reader (BIOLOG microstation) every $24 \mathrm{~h}$ for 7 days.

\section{Community Fingerprinting by Ribosomal Intergenic Spacer Analysis}

Molecular essays were conducted following DNA extraction from $500 \mathrm{mg}$ of soil for each sample in duplicate as previously described by Tanase et al. [31].

RISA assays were conducted with the following primers: ITSF (5-GTCGTAACAAGGTAGCCGTA-3) and ITSReub (5-GCCAAGGCATCCACC-3) on $25 \mathrm{ng}$ soil total DNA according to Cardinale et al. [32]. The reactions were carried out on an Eppendorf Mastercycler gradient thermocycler. Amplicons were visualized on $10.5 \%$ polyacrylamide gel and bands pattern analysis was made using Quantity One 1-D Analysis Software (BIO-RAD).

\section{Quantification of Total Bacteria in Soil Samples}

To estimate the total number of soil bacteria, a region of $16 \mathrm{~S} r R N A$ genes were directly amplified from diluted metagenomic DNA using universal primers Eub338 5-ACTCCTACGGGAGGCAGCAG-3(forward) and Eub518 5-ATTACCGCGGCTGCTGG-3 (reverse) in duplicate [33]. Reactions were carried out on a fast real-time PCR System900HT, by Applied Biosystems at a final volume of $20 \mu \mathrm{L}$ volume containing: $10 \mu \mathrm{L}$ Power SYBR Green PCR Master Mix (Applied Biosystems), $0.2 \mu \mathrm{L}(10 \mu \mathrm{M})$ of each primer, $1 \mu \mathrm{L}$ bovine serum albumin ( $3 \mathrm{mg} / \mathrm{ml}), 1 \mu \mathrm{L}$ DNA ( $\sim 25 \mathrm{ng})$ and distilled sterile water. Amplification conditions were as follows: $10 \mathrm{mins}$ at $95^{\circ} \mathrm{C}$ followed by 40 cycles at $95^{\circ} \mathrm{C}$ for $50 \mathrm{~s}$ and annealing at $57^{\circ} \mathrm{C}$ for $50 \mathrm{~s}$, and 
elongation at $72^{\circ} \mathrm{C}$ for $50 \mathrm{~s}$.

\section{Quantification of Alkane Monooxygenase Gene alkB in Soil Samples}

Quantification of alkB genes from soil samples was conducted in the same conditions as described for $16 S$ rRNA genes using degenerate primers: alkBFd 5-AACTACMTCGARCAYTACGG-3 (forward) and alkBRd 5-TGAMGATGTGGTYRCTGTTCC-3 (reverse), (where $\mathrm{M}=\mathrm{AC}, \mathrm{R}=\mathrm{AG}$ and $\mathrm{Y}=\mathrm{CT}$ ) [34].

Standards were constructed using 10 -fold serial dilution of $1500 \mathrm{bp} 16 \mathrm{~S}$ rRNA and a $550 \mathrm{bp}$ alkB purified amplicons from a known hydrocarbon degrader Tsukamurella sp. MH1 [35] known to have a single copy of alkB gene and two copies of $16 \mathrm{~S} r R N A$ in the genome. Standards ranged from $10^{-4}$ to $10^{-9}$ molecular copies, depending on each case (efficiency $=0.99$, $\mathrm{R} 2=0.999)$. For reproducibility confirmation, all standards were used in every reaction. Results were analyzed with the manufacturer's provided software.

\section{Data Analysis}

CLPP analysis was conducted as described by Garland [36]. A single time point data for each sample was selected according to corresponding temporal dataset, represented by color development over incubation time $(0-168 \mathrm{~h})$. The optimal time point represented by $72 \mathrm{~h}$ data was normalized according to Weber et al. [28] by the average well color development (AWCD). Normalized absorbance for well $\mathrm{k}$ was calculated as follows:

$$
\overline{A_{k}}=\frac{A_{k}-A_{0}}{\frac{1}{31} \sum_{i=1}^{31}\left(A_{i}-A_{0}\right)}
$$

$A_{i}-$ absorbance reading of well $i$

$\mathrm{A}_{0}$ - absorbance reading of control well

Eq. 1 denominator is AWCD

Based on carbon source utilization patterns, Shannon diversity index ( $\mathrm{H}$ index) was calculated as Weber and Ledge [37] described:

$$
H_{C L P P}=-\sum p_{i} \ln \left(p_{i}\right)
$$

$\mathrm{p}_{\mathrm{i}}-$ OD $590 \mathrm{~nm}$ at $72 \mathrm{~h}$

Even though it is commonly used in tracking and evaluating community shifts over time and space, in this case it was used to evaluates microbial community metabolic diversity changes in time.

On the other hand, the large amount of data, represented by OD from 31 wells with different carbon sources, was organized in 5 guilds: 1) carbohydrates, carboxylic acids, 3) amino acids, 4) amines and amides, 5) polymers [38]. Thus, highly complex 31-dimensional data was compressed into 5 dimensions, and the total carbon source utilization percentage was divided in 5 guilds accordingly.

Functional community divergence measure was represented by Euclidean distance [37] between twotime points: reference point, day 0 and every given moment following pollution. Euclidean distance in this case measured for all 31 dimensions (31 carbon sources) dissimilarities of any given time point and day 0 .

\section{Results and Discussion}

\section{Microbial Community Metabolic Dynamics}

CLPP profile analysis managed to capture a series of important events regarding functional diversity and metabolic dynamics of indigenous microbial community from initially pristine soil before and after kerosene pollution event. During the 80-day period of observation, the development of Shannon diversity index (Fig. 1) revealed a rapid increase until day 7, most probably due to the high metabolic activity of medium chain n-alkane degraders, compounds known to be more easily metabolized [39] by many microbial taxa. The following abrupt decrease, from day 7 to day 14, and the slow but consistent increase (until day 70) in diversity values could be associated with the microbial community adaptation, specialization and metabolic shifts from easily degraded n-alkanes to other kerosene compounds. Our Shannon diversity index data revealed comparable values with previous similar studies [40, 41].

\section{Guild Grouping}

EcoPlate carbon source utilization percentage for each guild (Fig. 2) continuously changed during our study without seeming to follow any set pattern. Noting the fact that patterns recorded on day 80 were highly different compared to all samples, especially

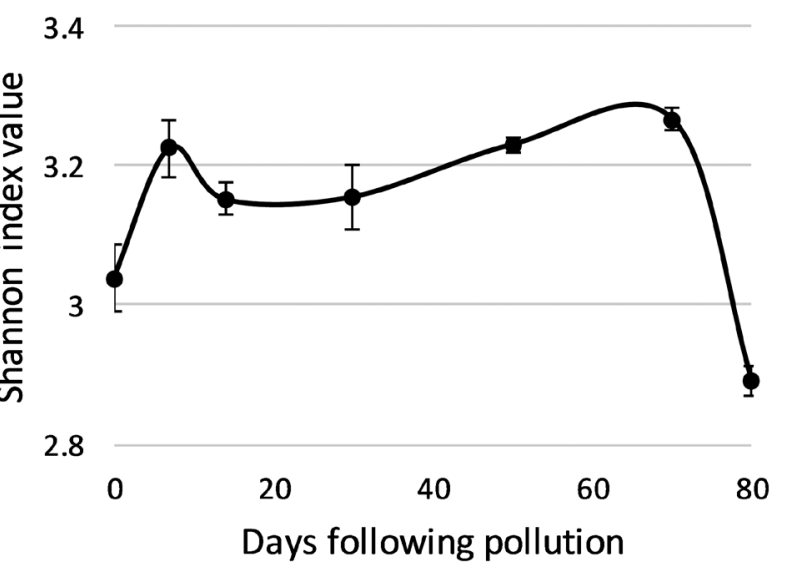

Fig. 1. Metabolic diversity represented by differences in substrate utilization following kerosene pollution (day 0 ) for 80 days, measured as Shannon diversity index value. 


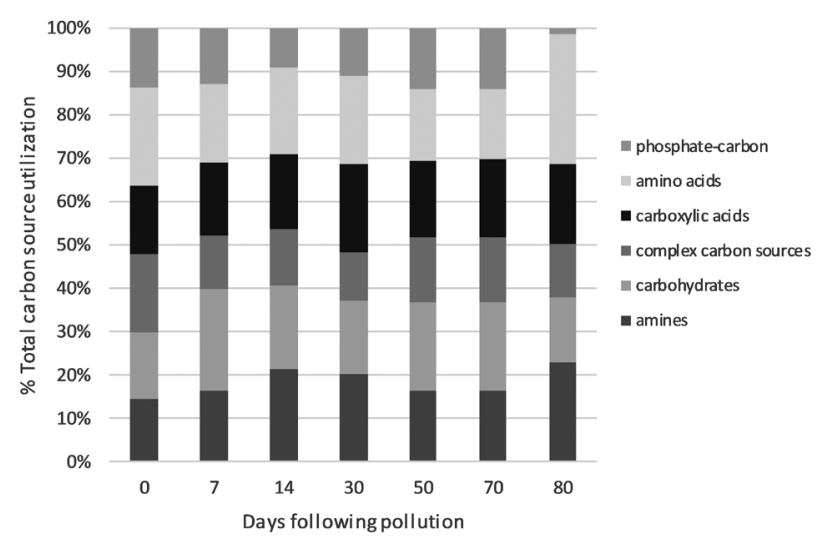

Fig. 2. Total carbon source utilization percentage divided in 6 different guilds, tracked over 80 days, following kerosene pollution.

day 0 , it can be assumed that, considering the studied time frame, the analyzed microbial community did not tend to return to its initial state. Carboxylic acids were well metabolized, being noted that these compounds are metabolic intermediates in $n$-alkane degradation pathway. All shifts recorded represent a highly dynamic response to kerosene pollution, considered a disturbing factor.

\section{Divergence}

Using Euclidean distance between CSUPs (community substrate utilization patterns) with reference to day 0 , we managed to capture divergence trends in bacterial communities following a kerosene pollution event. As seen in Fig. 3, indigenous communities diverged rapidly and drastically during the first 7 days of observation due to low survival rates to highly toxic pollutants [42], but mostly counted as a metabolic specialization for $n$-alkane degradation. After 7 days, community divergence reached a much steadier state,

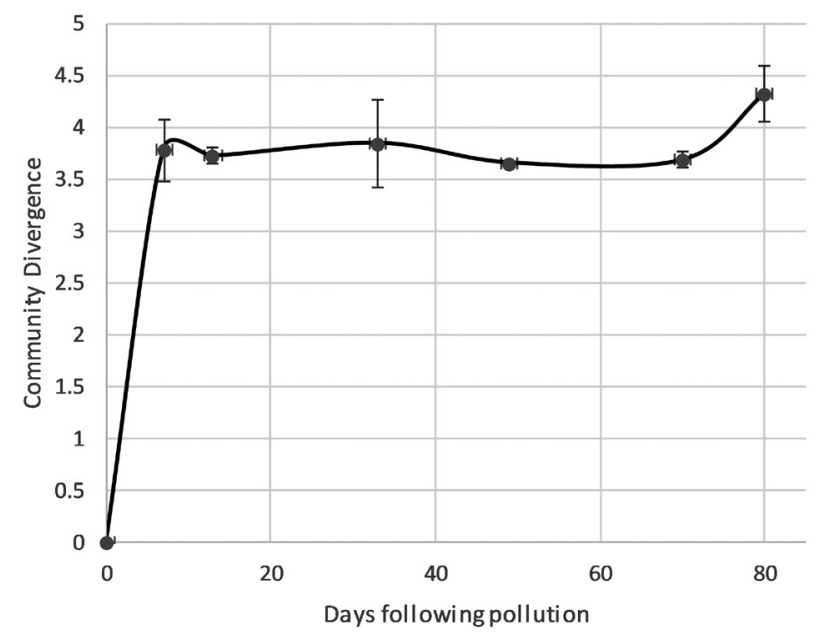

Fig. 3. Community divergence measured as Euclidean distance for 80 days, following kerosene pollution. obtained values being similar when compared to day 0 . In concordance with the observed results from guild grouping analysis, divergence trends also showed that the indigenous microbial community adapted rapidly to the harsh new environmental condition, subsequently specializing on using the given carbon sources. As mentioned before, data from day 80 highlighted the fact that, after restructuration events, the indigenous community diverged even more.

\section{Assessing Microbial Community Structure and alkB Genes}

RISA

ITS (internal transcribed spacer) phylotype revealed a total number of 38 OTUs, the maximum number of 31 being observed on day 0 , accounting for the indigenous microbial community's great taxonomic variation. A rapid decrease in OUTs number to 21 from day 0 to day 50 suggested in this case a taxonomic restructuration related to kerosene toxicity, but mostly to the availability of new complex carbon sources in the environment. Samples from days 70 and 80 revealed a second taxonomic restructuration, with OTU numbers reaching 10 , suggesting a highly specialized community comprising specific taxa with great tolerance and degradation abilities.

Based on a pairwise comparison of OTU presence/ absence, $43-90 \%$ of shared OTUs was observed through the entire analyzed period. A major bacterial community shift appeared up to day 70 , with a loss of between $33-41 \%$ for the first 50 days, followed by a significant decrease of $56 \%$ between samples from days 50 and 70 . A stable state was reached between days 70 to 80 , with a shared OTU of $90.9 \%$. It is generally assumed that regarding available carbon sources specific taxa will be selected, certain bacterial community individuals being able to adapt and multiply, highlighting once again the versatility and dynamics of indigenous communities [43].

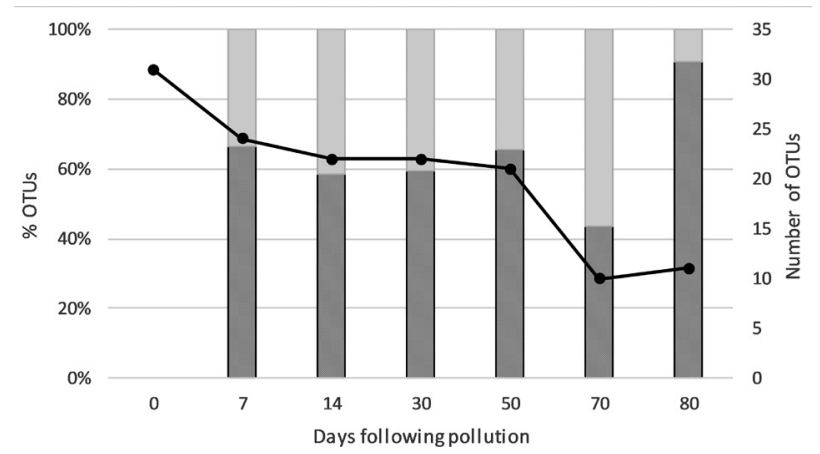

Fig. 4. OTU turnover for 80 days; the line represents the number of OTUs for every sample, and bars show the percentage of OTUs shared (striped)/not shared (not striped) between a sample and the previous one. 


\section{qPCR $16 S$}

The impact of kerosene pollution on the bacterial community was also analyzed by quantitative evaluation of $16 S$ rRNA gene copy number and resulting data was normalized with DNA extraction yields. As seen in Fig. 5, the amount of $16 \mathrm{~S}$ rRNA gene copies varied from $1.5 \times 10^{9}$ to $6.67 \times 10^{9}$, with the lowest value being determined after 7 days of pollutant exposure and the highest value reached after 70 days. After the decrease from day 0 to day 7 , as a response to given stress factor, kerosene exposure led to the selection of bacterial populations able to use it as a carbon source and energy, favoring the growth of certain individuals adapted to the contaminated environment. After day 7 the number of gene copies increased continuously, reaching a maximum level on day 70 , followed by a slight decrease from $6.67 \times 10^{9}$ to $6.01 \times 10^{9}$ copies for day 80 , justified by the decrease in kerosene concentration due to biodegradation events. Thus, the association of these opposite effects of pollutant exposure, a decrease in abundance and diversity because of kerosene toxicity, followed by an increase in abundance of specialized bacteria, determined the changes in structure and abundance of indigenous bacterial communities.

\section{qPCR alkB}

Accounted as an evaluation for metabolic activity correlated to $n$-alkanes degradation, the alkB genes copy number was estimated (Fig. 5). The dynamic trend regarding alkB genes copy number is similar to the one from $16 S r R N A$, excepting the fact that the copies amount was much higher, starting from $5.53 \times 10^{9}$ on day 0 and reaching $1.67 \times 10^{11}$ on day 70 . The significantly higher number compared to $16 \mathrm{~S} r R N A$ genes can suggest that the studied indigenous soil microbial community has a great biodegradation potential, comprising individuals with the enzymatic equipment suited for $n$-alkane catabolism. At the same time, it can be noted that some bacterial strains can have more than one alkB

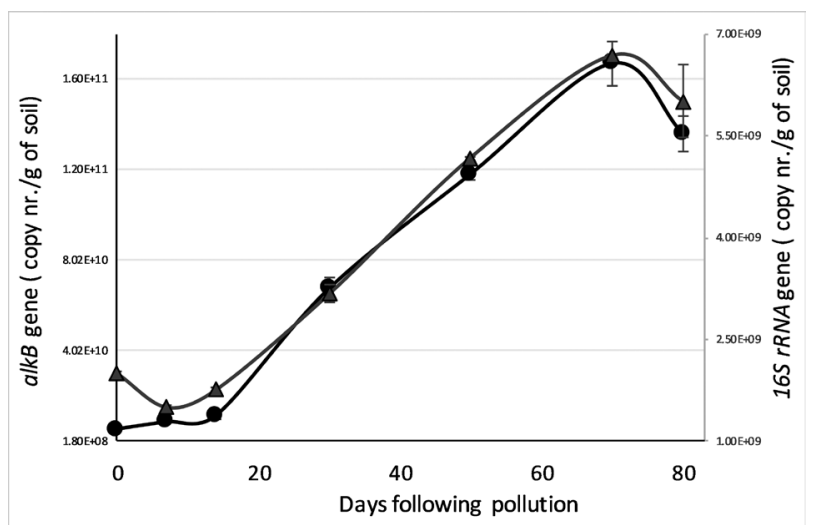

Fig. 5. Changes in $16 \operatorname{Sr} R N A(\mathbf{\Delta})$ and $\operatorname{alk} B(\bullet)$ gene copy numbers per gram of soil for 80 days, following kerosene pollution. gene. These aspects can explain the initial great number of alkB genes, but also the maximum value reached. As also observed for $16 S$ rRNA genes, at day 80 we noticed a decrease in gene numbers to $1.36 \times 10^{11}$, which can be directly correlated to the decrease of bacterial individuals.

\section{Conclusions}

This research brings valuable information in the field of microbial ecology, providing a detailed analysis regarding structural and functional changes in a soil microbial community during kerosene pollution. Novelty and originality of our result lies in the significant number of techniques, comprising metabolic profiles, molecular fingerprinting and gene quantification (16S rRNA and alkane hydroxylase - alkB) used for characterizing an indigenous microbial community from a pristine soil polluted with kerosene in controlled conditions.

\section{Acknowledgements}

This work was partially supported by the Executive Agency for Higher Education, Research, Development and Innovation Funding (13/2017 MARPLAST).

\section{Conflict of Interest}

The authors declare no conflict of interest.

\section{References}

1. TURKYILMAZ A., SEVIK H., CETIN M., AHMAIDA SALEH E.A. Changes in heavy metal accumulation depending on traffic density in some landscape plants. Polish Journal of Environmental Studies 27 (5), 1, 2018.

2. SEVIK H., CETIN M. Effects of water stress on seed germination for select landscape plants. Polish Journal of Environment Studies 24 (2), 689, 2015.

3. CETIN M., SEVIK H. Measuring the impact of selected plants on indoor $\mathrm{CO}_{2}$ concentrations. Polish Journal of Environmental Studies 25 (3), 973, 2016.

4. CETIN M., ADIGUZEL F., KAYA O., SAHAP A. Mapping of bioclimatic comfort for potential planning using GIS in Aydin. Environment, Development and Sustainability 20 (1), 361, 2018.

5. MATYKA M., KUŚ J. Influence of soil quality for yield and biometric features of Sida hermaphrodita L. Rusby. Polish Journal of Environmental Studies 27 (6), 2669, 2018.

6. SONG W., TONG X., ZHANG J., MENG P., LI J. How a root-microbial system regulates the response of soil respiration to temperature and moisture in a plantation. Polish Journal of Environmental Studies 27 (6), 2749, 2018.

7. KRAVKAZ KUSCU I.S., CETIN M., YIGIT N., SAVACI G., SEVIK H. Relationship between enzyme activity (urease-catalase) and nutrient element in soil use. Polish Journal of Environmental Studies 27 (5), 1, 2018. 
8. SINGH A., KUHAD R.C., WARD O.P. Biological remediation of soil: An overview of global market and available yechnologies. Advances in Applied Bioremediation. Springer Berlin Heidelberg. 17, 1, 2009.

9. SINGH R. Microorganism as a tool of bioremediation technology for cleaning environment: A review. Proceedings of the International Academy of Ecology and Environmental Sciences. 4 (1), 1, 2014.

10. CHEN M., XU P., ZENG G., YANG C., HUANG., ZHANG J. Bioremediation of soils contaminated with polycyclic aromatic hydrocarbons, petroleum, pesticides, chlorophenols and heavy metals by composting: Applications, microbes and future research needs. Biotechnology Advances 33 (6), 745, 2015.

11. MEGHARAJ M., RAMAKRISHNAN B., VENKATESWARLU K., SETHUNATHAN N., NAIDU R. Bioremediation approaches for organic pollutants: A critical perspective. Environment International 37 (8), 1362, 2011

12. SUTTON N.B., MAPHOSA F., MORILLO J.A., ALSOUD W.A., LANGENHOFF A.A.M., GROTENHUIS T., RIJNAARTS H.H.M, SMIDT H. Impact of longterm diesel contamination on soil microbial community structure. Applied and Environmental Microbiology 79 (2), 619, 2013.

13. GRIFFITHS B.S., PHILIPPOT L. Insights into the resistance and resilience of the soil microbial community. FEMS Microbiology Reviews 37 (2), 112, 2013.

14. ADILOĞLU S. Using Phytoremediation with Canola to Remove Cobalt from Agricultural Soils. Polish Journal of Environmental Studies 25 (6), 2251, 2016.

15. ANTONKIEWICZ J., KOŁODZIEJ B., BIELIŃSKA E. J., WITKOWICZ R., TABOR S. Using Jerusalem artichoke to extract heavy metals from municipal sewage sludge amended soil. Polish Journal of Environmental Studies 27 (2), 513, 2018.

16. TURKYILMAZ A., SEVIK H., CETIN M. The use of perennial needles as biomonitors for recently accumulated heavy metals. Landscape and Ecological Engineering 14 (1), 115, 2018.

17. ROY A.S., BARUAH R., BORAH., SINGH A.K., DEKA BORUAH H.P., SAIKIA N., DEKA M., DUTTA N., CHANDRA BORA T. Bioremediation potential of native hydrocarbon degrading bacterial strains in crude oil contaminated soil under microcosm study. International Biodeterioration \& Biodegradation 94, 79, 2014.

18. JUNG J., PHILIPPOT L., PARK W. Metagenomic and functional analyses of the consequences of reduction of bacterial diversity on soil functions and bioremediation in diesel-contaminated microcosms. Scientific Reports 6, 2016.

19. CUEVA S.C., RODRÍGUEZ C.H., CRUZ N.O.S., CONTRERAS J.A. R., MIRANDA J.L. Changes in bacterial populations during bioremediation of soil contaminated with petroleum hydrocarbons. Water Air and Soil Pollution 227 (3), 91, 2016.

20. LANGILLE M.G.I., ZANEVELD J., CAPORASO J.G., MCDONALD D., KNIGHTS D., REYES J.A., CLEMENTE J.C., BURKEPILE D.E., Vega Thurber R.L., KNIGHT R., BEIKO R.G., HUTTENHOWER C. Predictive functional profiling of microbial communities using 16S rRNA marker gene sequences. Nature Biotechnology 31 (9), 814, 2013.

21. MASON O.U., SCOTT N.M., GONZALEZ A., ROBBINSPIANKA A., BÆLUM J., KIMBREL J., BOUSKILL N.J., PRESTAT E., BORGLIN S., JOYNER D.C., FORTNEY
J.L., JURELEVICIUS D., STRINGFELLOW W.T., ALVAREZ-COHEN L., HAZEN T.C., KNIGHT R., GILBERT J.A., JANSSON J.K. Metagenomics reveals sediment microbial community response to Deepwater Horizon oil spill. The ISME Journal 8 (7), 1464, 2014.

22. ZAVERI P., PATEL R., PATEL M., SARODIA D., MUNSHI N.S. Modification of extraction method for community DNA isolation from salt affected compact wasteland soil samples. MethodsX 4, 63, 2017.

23. FAUST K., LAHTI L., GONZE D., DE VOS W.M., RAES J. Metagenomics meets time series analysis: unraveling microbial community dynamics. Current Opinion in Microbiology 25, 56, 2015.

24. LIU B., LI Y., ZHANG X., WANG J., GAO M. Effects of chlortetracycline on soil microbial communities: Comparisons of enzyme activities to the functional diversity via Biolog EcoPlates ${ }^{\mathrm{TM}}$. European Journal of Soil Biology 68, 69, 2015.

25. PESSACQ J., MEDINA R., TERADA C., BIANCHINI F.E., MORELLI I.S., PANNO M.T. Assessment of the responsiveness to different stresses of the microbial community from long-term hydrocarbon-contaminated soils. Water Air and Soil Pollution 226 (2), 20, 2015.

26. ZAVERI P., MUNSHI N., VAIDYA A., JHA S., KUMAR G.N. Functional microbial diversity dynamics in common effluent treatment plants of South Gujarat and hydrocarbon degradation. Canadian Journal of Microbiology 61 (6), $389,2015$.

27. RUTGERS M., WOUTERSE M., DROST S.M., BREURE A.M., MULDER C., STONE D., CREAMER R.E., WINDING A., BLOEM J. Monitoring soil bacteria with community-level physiological profiles using Biolog ${ }^{\mathrm{TM}}$ ECO-plates in the Netherlands and Europe. Applied Soil Ecology 97, 23, 2016.

28. WEBER K.P., GROVE J.A., GEHDER M., ANDERSON W.A., LEGGE R.L. Data transformations in the analysis of community-level substrate utilization data from microplates. Journal of Microbiological Methods 69 (3), 461, 2007.

29. WEBER K.P., MITZEL M.R., SLAWSON R.M., LEGGE R.L. Effect of ciprofloxacin on microbiological development in wetland mesocosms. Water Research 45 (10), 3185, 2011.

30. BUTTON M., WEBER K., NIVALA J., AUBRON T., MÜLLER R.A. Community-Level Physiological Profiling of microbial communities in constructed wetlands: Effects of sample preparation. Applied Biochemistry and Biotechnology 178 (5), 960, 2016.

31. TANASE A.-M., MEREUTA I., CHICIUDEAN I., IONESCU R., MILEA L., CORNEA C.P., VASSU T., STOICA I. Comparison of total DNA extraction methods for microbial community form polluted soil. Agriculture and Agricultural Science Procedia 6, 616, 2015.

32. CARDINALE M., BRUSETTI L., QUATRINI P., BORIN S., PUGLIA A.M., RIZZI A., ZANARDINI E., SORLINI C., CORSELli C., DAFFONCHIO D. Comparison of different primer sets for use in automated ribosomal intergenic spacer analysis of complex bacterial communities. Applied and Environmental Microbiology 70 (10), 6147, 2004

33. JACQUIOD S., FRANQUEVILLE L., CÉCILLON S., VOGEL T. M., SIMONET P. Soil bacterial community shifts after chitin enrichment: An integrative metagenomic approach. PLOS ONE 8 (11), e79699, 2013.

34. POWELL S.M., FERGUSON S.H., BOWMAN J.P., SNAPE I. Using Real-Time PCR to assess changes in the 
hydrocarbon-degrading microbial community in antarctic soil during bioremediation. Microbial Ecology 52 (3), 523, 2006.

35. CHICIUDEAN I., NIE Y., TĂNASE A.-M., STOICA I., WU X.-L. Complete genome sequence of Tsukamurella sp. MH1: A wide-chain length alkane-degrading actinomycete. Journal of Biotechnology 268, 1, 2018.

36. GARLAND J.L. Analytical approaches to the characterization of samples of microbial communities using patterns of potential C source utilization. Soil Biology and Biochemistry 28 (2), 213, 1996.

37. WEBER K.P., LEGGE R.L. Dynamics in the bacterial community-level physiological profiles and hydrological characteristics of constructed wetland mesocosms during start-up. Ecological Engineering 37 (5), 666, 2011.

38. ZAK J.C., WILLIG M.R., MOORHEAD D.L., WILDMAN H.G. Functional diversity of microbial communities: A quantitative approach. Soil Biology and Biochemistry 26 (9), 1101, 1994.
39. IRVINE R.L., SIKDAR S.K. Biodegradation Technology Developments: Principles and Practice. CRC Press, 1997.

40. BOSHOFF M., DE JONGE M., DARDENNE F., BLUST R., BERVOETS L. The impact of metal pollution on soil faunal and microbial activity in two grassland ecosystems. Environmental Research 134, 169, 2014.

41. FRĄC M., OSZUST K., LIPIEC J. Community Level Physiological Profiles (CLPP), characterization and microbial activity of soil amended with dairy sewage sludge. Sensors 12 (3), 3253, 2012.

42. JIANG Z., HUANG Y., XU X., LIAO Y., SHOU L., LIU J., CHEN Q., ZENG J. Advance in the toxic effects of petroleum water accommodated fraction on marine plankton. Acta Ecologica Sinica 30 (1), 8, 2010.

43. JOHNSON D.R., GOLDSCHMIDT F., LILJA E.E., ACKERMANN M. Metabolic specialization and the assembly of microbial communities. The ISME Journal 6 (11), 1985, 2012. 
